\title{
PERMASALAHAN DAN SOLUSI PROGRAM INDONESIA PINTAR DALAM MEWUJUDKAN PEMERATAAN PENDIDIKAN DI KABUPATEN BENGKAYANG
}

\author{
Bella Ghia Dimmera ${ }^{1)}$ dan Pebria Dheni Purnasari ${ }^{2)}$ \\ ${ }^{1,2}$ Program Studi Manajemen, Institut Shanti Bhuana \\ ${ }^{1,2}$ Jln. Bukit Karmel No.1, Bengkayang, Kalimantan Barat, 79211 \\ E-mail: bellaghia@shantibhuana.ac.id ${ }^{1)}$,pebria.dheni@shantibhuana.ac.id ${ }^{2)}$
}

\begin{abstract}
ABSTRAK
Penelitian ini bertujuan untuk mendeskripsikan permasalahan Program Indonesia Pintar di Kabupaten Bengkayang dan alternatif solusi penyelesaiannya yang diperlukan dalam mewujudkan pemerataan pendidikan di Kabupaten Bengkayang. Pendekatan yang dipakai dalam penelitian ini adalah pendekatan deskriptif kualitatif. Adapun responden dalam penelitian ini adalah pemerintah daerah Kabupaten Bengkayang, Kepala Sekolah, Guru, peserta didik penerima KIP, serta orang tua peserta didik penerima KIP. Pelaksanaan PIP dapat mendukung upaya pemerataan pendidikan, hal ini ditandai dengan adanya PIP dapat membantu keluarga peserta didik yang kurang mampu, sehingga peserta didik yang terkendala dengan biaya sekolah dapat tetap merasakan pendidikan yang layak dan merata. Hasil yang dicapai adalah terdapat enam permasalahan dari pandangan pemerintah daerah, Kepala Sekolah, guru, peserta didik, dan masyarakat. Permasalahan tersebut antara lain pendistribusian KIP yang tidak merata, pencairan dana PIP tidak secara utuh, peserta didik penerima KIP tidak tepat sasaran, masih ada orang tua penerima KIP yang tidak mengelola dana bantuan PIP dengan baik, masyarakat kurang dilibatkan dalam pelaksanaan PIP, serta sebagian besar masyarakat kurang memahami kebijakan maupun mekanisme penyaluran dana bantuan PIP. Alternatif solusi yang diberikan adalah terus menerus mendorong adanya keterlibatan semua pihak untuk bekerjasama saling memantau dan mengevaluasi pelaksanaan PIP secara menyeluruh dan seimbang.
\end{abstract}

Kata kunci: Program Indonesia Pintar, Kartu Indonesia Pintar, Pemerataan Pendidikan, Permasalahan Pendidikan, Alternatif Solusi

\section{PENDAHULUAN}

Pemerataan pendidikan dapat menjadi tolok ukur bagi kemajuan suatu wilayah dengan perbaikan dan penataan pendidikan yang baik secara terus menerus seiring perkembangan zaman. Pemerataan pendidikan ditandai dengan adanya dukungan dari pemerintah dalam memantau dan mengevaluasi pelaksanaan pendidikan sebagai upaya untuk meningkatkan mutu pendidikan. Pemerataan pendidikan juga merupakan cakupan dari program desentralisasi, di mana pemerintah daerah memiliki kewenangan untuk menetapkan kebijakan yang disesuaikan dengan kebutuhan daerah tersebut demi mencapai tujuan (Aristo, 2019). Dengan demikian, untuk mencapai pemerataan pendidikan maka dibutuhkan koordinasi yang baik antara pemerintah pusat dan daerah. Oleh karena itu, para pemimpin bangsa perlu memikirkan dengan matang kebijakan-kebijakan yang sasarannya adalah untuk merealisasikan pemerataan pendidikan.

Program Indonesia Pintar (PIP) merupakan salah satu kebijakan pemerintah dalam upaya pemerataan pendidikan. Pemerintah telah berupaya keras menggalakkan Program Indonesia Pintar (PIP) untuk memenuhi hak setiap warga negara dalam memperoleh layanan pendidikan, yakni melalui Kartu Indonesia
Pintar (KIP) yang diluncurkan oleh pemerintah di bawah naungan Kementerian Pendidikan dan Kebudayaan sebagaimana diatur dalam Peraturan Menteri Pendidikan dan Kebudayaan RI Nomor 9 Tahun 2018 tentang Perubahan atas Peraturan Menteri Pendidikan dan Kebudayaan Nomor 19 Tahun 2016 tentang Petunjuk Teknis Program Indonesia Pintar. Adapun tujuan dari PIP ini adalah untuk membantu biaya sekolah peserta didik yang kurang mampu dari tingkat Sekolah Dasar (SD) hingga Sekolah Menengah Atas (SMA) (Septiandika, 2017). Hal ini sebagaimana diungkapkan oleh (Rohaeni \& Saryono, 2018) bahwa kebijakan PIP melalui KIP yang dikeluarkan oleh pemerintah di bawah wewenang Kementerian dan Kebudayaan bertujuan untuk menyediakan bantuan terkhusus untuk siswa miskin sehingga dapat melanjutkan sekolahnya, dengan demikian sasaran dari kebijakan ini adalah untuk mencegah anak putus sekolah. Untuk mencapai tujuan tersebut, dibutuhkan peran setiap sekolah dalam mengimplementasikan kebijakan PIP melalui KIP secara operasional dengan baik agar PIP ini tepat sasaran dan sesuai dengan apa yang diharapkan. Namun, dalam hal ini masih banyak peserta didik yang putus sekolah dengan alasan kurangnya biaya pendidikan sekolah. Selain itu, masih adanya peserta didik yang tergolong 
tidak mampu namun tidak terdaftar sebagai penerima dana KIP, serta peserta didik yang sudah menerima KIP pun masih juga kesulitan membayar biaya sekolah dan kesulitan memenuhi perlengkapan kebutuhan sekolahnya.

Dalam pemerataan pendidikan, selain dilakukan reorientasi peran pemerintah, juga pentingnya secara sistematis dan konsisten peran sekolah melakukan sosialisasi untuk menyadarkan masyarakat tujuan PIP yang harus digunakan sesuai dengan kebutuhan dan kepentingan mereka. Peluang untuk mewujudkan pemerataan pendidikan di Kabupaten Bengkayang sudah sangat diperlukan. Hal ini dilandasi mengingat Kabupaten Bengkayang berada di daerah perbatasan Kalimantan Barat yang lokasinya strategis berbatasan langsung dengan negara tetangga, Malaysia, sehingga dalam upaya mengatasi permasalahan PIP secara maksimal, masyarakat diharapkan bisa mendapatkan pendidikan yang layak dan merata.

Program Indonesia Pintar (PIP) yang diwujudkan melalui pendistribusian Kartu Indonesia Pintar (KIP) diharapkan dapat mengatasi masalah kemiskinan dan juga meningkatkan mutu pendidikan serta dapat menjamin peserta didik dari keluarga tidak mampu tetap bersekolah sehingga mampu melanjutkan pendidikan di jenjang yang lebih tinggi. Pencapaian tersebut telah dibuktikan oleh (Rohaeni \& Saryono, 2018) melalui penelitiannya di mana kebijakan PIP melalui KIP telah memberikan dampak yang positif bagi siswa yang menerima bantuan tersebut sehingga dapat mewujudkan pemerataan pendidikan. Kondisi serupa juga telah dibuktikan melalui penelitian (Yusup, Ismanto, \& Wasitohadi, 2019) di mana hasilnya menunjukkan bahwa pelaksanaan PIP telah berjalan sesuai yang diharapkan, oleh karena itu dapat membantu siswa dalam memenuhi kebutuhan pendidikan dan meningkatkan akses pendidikan yang merata bagi siswa kurang mampu bahkan dapat meningkatkan rasa antusias siswa untuk terus sekolah, meskipun demikian dalam pelaksanaannya PIP perlu dievaluasi secara berkala karena ditemui beberapa kesenjangan antara pelaksanaan dan desain nya. Temuan-temuan tersebut pada kenyataannya berbeda dengan kondisi di wilayah Bengkayang. Melalui hasil observasi dan studi lapangan pada tahap awal, peneliti menemukan bahwa masih banyak siswa yang nyatanya belum dapat memenuhi kebutuhan sekolah meskipun menerima PIP, bahkan ada beberapa siswa yang putus sekolah. Hal ini tentunya menimbulkan kesenjangan antara sasaran kebijakan PIP dengan kondisi nyata di lapangan. Kedua penelitian tersebut, dari sisi daerah telah dilakukan di daerah yang cukup maju, sedangkan wilayah Bengkayang merupakan wilayah perbatasan yang hingga tahun 2019 tergolong sebagai daerah 3T (Tertinggal, Terluar, Terdepan) (Purnasari \& Sadewo, 2019). Kondisi tersebut tentunya membuat upaya penerapan kebijakan PIP bukan hal yang mudah terutama menyangkut permasalahan penyaluran dana PIP yang dominan dirasakan oleh penerima KIP, Kepala
Sekolah, guru dan pemerintah daerah. Hal pokok yang harus dicari alternatif solusinya adalah bagaimana pelaksanaan PIP dapat mewujudkan pemerataan pendidikan di Kabupaten Bengkayang. Oleh karena itu, penelitian ini perlu dilakukan karena dapat memberikan gambaran dan penjelasan rinci mengenai permasalahan Program Indonesia Pintar di Kabupaten Bengkayang yang dirasakan oleh pemerintah daerah, Kepala Sekolah, guru, peserta didik, dan masyarakat, serta alternatif solusi penyelesaiannya.

\section{RUANG LINGKUP}

Kondisi Pendidikan di Kabupaten Bengkayang saat ini dapat dikatakan sangat memprihatinkan. Permasalahan yang berkaitan dengan layanan pendidikan masih termasuk kendala yang belum dapat diatasi karena belum semua masyarakat mendapatkan pendidikan yang selayaknya. Kajian terhadap permasalahan Program Indonesia Pintar dari pandangan pemerintah daerah, Kepala Sekolah, guru, peserta didik, dan masyarakat dapat memberikan alternatif solusi sebagai dasar untuk mewujudkan pemerataan pendidikan. Memperhatikan kondisi tersebut, maka rumusan dalam penelitian ini adalah:

1. Bagaimana permasalahan Program Indonesia Pintar di Kabupaten Bengkayang yang dirasakan oleh pemerintah daerah, Kepala Sekolah, guru, peserta didik, dan masyarakat sebagai stakeholder?

2. Bagaimana alternatif solusi penyelesaiannya menurut pandangan stakeholder di Kabupaten Bengkayang?

\section{BAHAN DAN METODE}

Kajian yang menjadi fokus dalam penelitian ini adalah pemerataan pendidikan dan Program Indonesia Pintar. Pemerataan pendidikan dapat diartikan sebagai pemerataan kesempatan untuk memperoleh pendidikan telah lama menjadi masalah yang mendapat perhatian, terutama di negara sedang berkembang. Hal ini tidak terlepas dari makin tumbuhnya kesadaran bahwa pendidikan mempunyai peran penting dalam pembangunan bangsa, seiring juga dengan berkembangnya demokratisasi pendidikan dengan semboyan education for all.

Pemerataan pendidikan mencakup dua aspek penting yaitu Equality dan Equity. Equality atau persamaan mengandung arti persamaan kesempatan untuk memperoleh pendidikan, sedangkan equity bermakna keadilan dalam memperoleh kesempatan pendidikan yang Sama diantara berbagai kelompok dalam masyarakat. Akses terhadap pendidikan yang merata berarti semua penduduk usia sekolah telah memperoleh kesempatan pendidikan, sementara itu akses terhadap pendidikan telah adil jika antar kelompok bisa menikmati pendidikan secara sama. Coleman dalam bukunya Equality of educational opportunity mengemukakan secara konvensional konsep pemerataan yakni: pemerataan aktif dan pemerataan pasif. Pemerataan pasif adalah pemerataan yang lebih menekankan pada 
kesamaan memperoleh kesempatan untuk mendaftar di sekolah, sedangkan pemerataan aktif bermakna kesamaan dalam memberi kesempatan kepada muridmurid terdaftar agar memperoleh hasil belajar setinggitingginya (Mujahidun, 2016). Dalam pemahaman seperti ini pemerataan pendidikan mempunyai makna yang luas tidak hanya persamaan dalam memperoleh kesempatan pendidikan, tetapi juga setelah menjadi peserta didik harus diperlakukan sama guna memperoleh pendidikan dan mengembangkan potensi yang dimilikinya untuk dapat berwujud secara optimal.

Dengan demikian dimensi pemerataan pendidikan mencakup hal-hal yaitu equality of access, equality of survival, equality of output, dan equality of outcome. Apabila dimensi-dimensi tersebut menjadi landasan dalam mendekati masalah pemerataan pendidikan, Nampak betapa rumit dan sulitnya menilai pemerataan pendidikan yang dicapai oleh suatu daerah, apalagi bagi negara yang sedang membangun sehingga kendala pendanaan Nampak masih cukup dominan baik dilihat dari sudut kuantitas maupun efektivitas.

Program Indonesia Pintar adalah pemberian bantuan tunai dari pemerintah kepada anak usia sekolah dari keluarga kurang mampu yang ditandai dengan pemberian Kartu Indonesia Pintar (KIP) sebagai kelanjutan dari Program Bantuan Peserta didik Miskin. Kartu Indonesia Pintar kepada anak usia sekolah dari keluarga kurang mampu yang memiliki Kartu Keluarga Sejahtera (KKS) dengan tujuan menjamin seluruh anak usia sekolah dapat menempuh pendidikan.

Menurut Peraturan Menteri Pendidikan dan Kebudayaan RI Nomor 9 Tahun 2018 tentang Perubahan atas Peraturan Menteri Pendidikan dan Kebudayaan Nomor 19 Tahun 2016 tentang Petunjuk Teknis Program Indonesia Pintar yang selanjutnya disebut PIP adalah bantuan berupa uang tunai dari pemerintah yang diberikan kepada peserta didik yang orang tuanya tidak atau kurang mampu membiayai pendidikannya, sebagai kelanjutan dan perluasan sasaran dari Program Bantuan Peserta didik Miskin (BSM). Peserta didik adalah anggota masyarakat yang berusaha mengembangkan potensi diri melalui proses pembelajaran yang tersedia pada jalur, jenjang, jenis dan pendidikan tertentu. Kartu Indonesia Pintar, yang selanjutnya disebut KIP adalah kartu yang diberikan kepada anak dari keluarga pemegang Kartu Perlindungan Sosial (KPS) atau Kartu Keluarga Sejahtera (KKS) sebagai penanda atau Identitas untuk mendapat manfaat PIP.

Pemberian bantuan KIP maupun bantuan pendidikan lainnya guna mendukung wajib belajar bertujuan untuk meringankan beban biaya yang terlalu berat bagi orang tua yang berasal dari status ekonomi bawah. Bantuan ini diharapkan dapat meningkatkan partisipasi peserta didik dalam bersekolah dan mencegah anak putus sekolah. Pemerintah memberikan bantuan pendidikan berupa KIP bagi anak-anak yang rawan putus agar dapat mencukupi kebutuhan pendidikan mereka. Pengalokasian Dana bantuan ini ditujukan untuk mencukupi kebutuhan pendidikan peserta didik diluar biaya operasional sekolah, biaya transportasi, uang saku dan lain-lain.

Kartu Indonesia Pintar (KIP) diberikan kepada anak usia 6 sampai dengan 21 tahun sebagai penanda atau identitas untuk menjadi prioritas sasaran penerima dana/ manfaat PIP apabila anak telah terdaftar sebagai peserta didik di lembaga pendidikan formal atau lembaga pendidikan nonformal.

Jenis penelitian yang digunakan adalah penelitian kualitatif-deskriptif. Metode penelitian kualitatifdeskriptif biasanya disebut metode penelitian yang memperoleh data apa adanya, dalam kondisi di mana hasilnya tidak dimanipulasi atau tanpa mengubah variabel-variabel yang diteliti, namun lebih menekankan pada makna sesuai fakta yang ada. Instrumen yang digunakan dalam penelitian kualitatif adalah peneliti itu sendiri, oleh sebab itu peneliti harus mempunyai wawasan yang luas untuk dapat mewawancarai, menganalisis, dan konstruksi situasi sosial yang diteliti agar apa yang diteliti lebih jelas dan mempunyai makna.

Penelitian kualitatif sebagai metode penelitian yang berdasarkan pada filsafat positivisme, digunakan untuk meneliti pada kondisi objek alamiah, sehingga instrumen kunci adalah peneliti itu sendiri, teknik pengumpulan data dengan triangulasi, analisis data dengan menarik kesimpulan dari khusus ke umum (bersifat induktif), dan hasil penelitian kualitatif lebih menekankan makna yang terjadi daripada generalisasi, (Sugiyono 2010).

Pendekatan deskriptif berusaha mendeskripsikan keseluruhan gejala atau keadaan apa adanya yang terjadi di lapangan pada saat penelitian dilakukan, (Mukhtar 2013). Pendekatan deskriptif merupakan penelitian yang berusaha untuk menuturkan pemecahan masalah yang ada sekarang berdasarkan data yang diperoleh lebih lengkap, lebih mendalam, kredibel, dan bermakna sehingga tujuan penelitian dapat tercapai.

Berdasarkan uraian di atas dapat disimpulkan bahwa penelitian ini menggunakan pendekatan deskriptif dengan metode kualitatif karena penelitian ini bertujuan untuk mengetahui permasalahan yang terjadi dan menggambarkan keadaan yang tampak mengenai Program Indonesia Pintar dalam mewujudkan pemerataan pendidikan di Kabupaten Bengkayang, serta alternatif solusinya. Metode pengumpulan data dalam pelaksanaan penelitian ini menggunakan data primer dan data sekunder. Sumber data primer yang digunakan dalam penelitian ini diperoleh melalui wawancara secara mendalam sesuai dengan waktu yang telah disepakati kepada para responden, yaitu pihak pemerintah daerah Kabupaten Bengkayang, Kepala Sekolah, Guru, peserta didik penerima KIP, serta orang tua peserta didik penerima KIP. Sedangkan sumber data sekunder diperoleh melalui studi pustaka yang terdiri dari jurnal, laporan ilmiah, laporan resmi pemerintah, dan bahanbahan lain yang relevan dengan topik penelitian. Penelitian ini dilaksanakan di salah satu SD di Kabupaten Bengkayang yaitu SDN 11 Kelampe, Kabupaten Bengkayang, Kalimantan Barat. 
Wawancara secara mendalam dilakukan sesuai dengan waktu yang telah disepakati bersama para responden, dan dilaksanakan dari tanggal 12 Maret 2020 sampai dengan 10 September 2020. Seluruh responden aktif berpartisipasi dalam penelitian ini sehingga penelitian ini dapat berjalan dengan lancar.

Adapun tahapan-tahapan yang dilakukan dalam penelitian ini dengan menggunakan analisis kualitatif interaktif, sebagai berikut:

1. Melakukan analisis permasalahan dengan observasi awal dengan mengunjungi langsung pihak Dinas Pendidikan dan Kebudayaan Kabupaten Bengkayang.

2. Melakukan wawancara dengan Kepala Bidang Pembinaan SD di Dinas Pendidikan dan Kebudayaan Kabupaten Bengkayang, kepala sekolah, guru, dan masyarakat di SDN 11 Kelampe Kabupaten Bengkayang berkaitan dengan permasalahan PIP di Kabupaten Bengkayang dan alternatif solusi penyelesaiannya sesuai dengan pedoman wawancara yang telah dibuat.

3. Melakukan wawancara dengan peserta didik dan orang tua peserta didik yang sudah menerima KIP untuk melihat pandangan terhadap permasalahan PIP sesuai dengan pedoman wawancara yang telah dibuat.

4. Mencatat hal-hal yang penting dari penjabaran para responden;

5. Mengategorikan catatan-catatan dan memilah-milah data yang akan dianalisis;

6. Melengkapi data dengan cara mempelajari isi data baik berupa hasil observasi dan hasil wawancara serta hasil dokumentasi di lapangan;

7. Menganalisis hasil kajian data dan menyimpulkannya. Peneliti membuat kesimpulan berdasarkan data yang telah diproses melalui reduksi dan penyajian data. Kesimpulan yang dikemukakan pada tahap awal didukung oleh bukti-bukti yang valid dan konsisten saat peneliti kembali ke lapangan mengumpulkan data permasalahan dan solusi PIP untuk mewujudkan pemerataan pendidikan di Kabupaten Bengkayang, sehingga kesimpulan yang dikemukakan oleh peneliti merupakan kesimpulan yang kredibel.

\section{PEMBAHASAN}

Penelitian ini dilakukan di wilayah Bengkayang di lingkup pendidikan, sehingga responden dalam penelitian ini dipilih berdasarkan kebutuhan peneliti terkait sumber data mengenai pelaksanaan Program Indonesia Pintar. Berikut dipaparkan hasil dan pembahasan dalam penelitian ini.

\subsection{Pelaksanaan Program Indonesia dalam Mewujudkan Pemerataan Pendidikan di Kabupaten Bengkayang \\ Pemerintah daerah Kabupaten Bengkayang telah} mengimplementasikan Program Indonesia Pintar (PIP) dengan skema dan tahapan, antara lain menerima SK penetapan peserta didik yang mendapatkan dana PIP yang diterbitkan oleh Kementerian Pendidikan dan Kebudayaan, dan mengirimkan daftar nama peserta didik yang menerima dana PIP kepada sekolah terkait agar pihak sekolah dapat memberitahukan kepada peserta didik mengenai waktu pengambilan dana bantuan PIP. Setelah melalui beberapa tahapan, peserta didik penerima KIP dapat mengambil dana bantuan di lembaga penyalur yang telah ditunjuk. Dalam pelaksanaan PIP melalui pendistribusian KIP dilakukan dengan syarat setiap peserta didik yang diusulkan mendapatkan KIP harus memiliki Surat keterangan miskin (SKM).

Menurut Peraturan Menteri Pendidikan dan Kebudayaan RI Nomor 9 Tahun 2018 tentang Perubahan atas Peraturan Menteri Pendidikan dan Kebudayaan Nomor 19 Tahun 2016 tentang Petunjuk Teknis Program Indonesia Pintar yang selanjutnya disebut PIP adalah bantuan berupa uang tunai dari pemerintah yang diberikan kepada peserta didik yang orang tuanya tidak atau kurang mampu membiayai pendidikannya, sebagai kelanjutan dan perluasan sasaran dari Program Bantuan Peserta didik Miskin (BSM). Pemberian bantuan PIP maupun bantuan pendidikan lainnya guna mendukung wajib belajar bertujuan untuk meringankan beban biaya yang terlalu berat bagi orang tua yang berasal dari status ekonomi ke bawah. Bantuan ini diharapkan dapat meningkatkan partisipasi peserta didik dalam bersekolah dan mencegah anak putus sekolah. Pemerintah memberikan bantuan pendidikan berupa KIP bagi anakanak yang rawan putus sekolah agar dapat mencukupi kebutuhan pendidikan mereka. Pengalokasian dana bantuan ini ditujukan untuk mencukupi kebutuhan pendidikan peserta didik diluar biaya operasional sekolah, biaya transportasi, uang saku dan lain-lain. Mekanisme pelaksanaan PIP ialah sekolah mengirimkan data ke Dinas Pendidikan untuk diteruskan ke Kementerian Pendidikan dan Kebudayaan. Proses selanjutnya, yaitu mengundang peserta didik penerima KIP untuk diberikan informasi mengenai hal terkait, (Astuti, 2017).

Dalam menjalankan fungsinya, pemerintah daerah Kabupaten Bengkayang bekerja sama dengan pihak sekolah untuk melakukan sosialisasi mengenai PIP. Sosialisasi yang dilakukan oleh Pemerintah daerah Kabupaten Bengkayang dan pihak sekolah dilaksanakan dengan maksud memberikan penjelasan mengenai sistem, tujuan, sasaran, kebijakan, serta prosedur maupun mekanisme dalam penyaluran dana PIP. Pihak-pihak yang terlibat dalam pelaksanaan sosialisasi adalah komite sekolah, orang tua peserta didik, dan peserta didik. Lebih lanjut ditegaskan dalam sosialisasi bahwa bantuan dana PIP untuk memenuhi kebutuhan sekolah, serta diprioritaskan untuk peserta didik yang berasal dari keluarga miskin dan menarik peserta didik kurang mampu untuk bersekolah kembali agar dapat mencegah angka putus sekolah. Namun demikian, pelaksanaan PIP belum sepenuhnya mampu menarik kembali peserta didik yang sudah putus sekolah, karena dana bantuan 
yang didapatkan masih sangat terbatas, selain itu dana bantuan PIP juga diterima langsung oleh peserta didik, sehingga pemerintah daerah tidak bisa mengatur peserta didik ataupun orang tuanya dalam mengelola keuangan bantuan PIP tersebut.

Penyaluran dana PIP di Kabupaten Bengkayang sangatlah tepat, melihat kondisi penduduknya masih ada yang berasal dari penduduk miskin. Penduduk miskin di Kabupaten Bengkayang sebanyak 17.690 penduduk atau sebesar 6,96 persen dari total penduduk Kabupaten Bengkayang, Meskipun demikian, Kabupaten Bengkayang menempati urutan ketujuh persentase yang terendah di Provinsi Kalimantan Barat. Namun, harus diakui dengan tingkat ekonomi yang rendah, maka sedikit peluang masyarakat di Kabupaten Bengkayang memperoleh pendidikan sesuai keinginannya. Pada sisi ini, sepintas dapat dipahami bahwa selama ini belum semua masyarakat Kabupaten Bengkayang dapat merasakan pendidikan yang merata. Jika hendak dicermati, maka salah satu persoalan pemerataan pendidikan dapat disebabkan oleh perbedaan tingkat sosial ekonomi masyarakat.

Sekolah-sekolah di Kabupaten Bengkayang masih banyak berada di pedesaan yang infrastruktur nya masih belum memadai mengakibatkan masyarakat kesulitan untuk mengakses informasi mengenai penyaluran dana PIP, serta memerlukan biaya transportasi yang cukup besar untuk mengambil dana bantuan PIP di Lembaga penyalur yang telah ditunjuk. Dalam hal ini, pemerintah daerah dan pihak sekolah telah berupaya mencari solusi untuk meringankan beban masyarakat setempat, sehingga mereka juga bisa memperoleh dana PIP tanpa merasa rugi telah mengeluarkan biaya transportasi yang lebih besar daripada dana PIP yang didapatkan. Hal ini menunjukkan bahwa Pemerintah daerah Kabupaten Bengkayang maupun pihak sekolah telah berperan aktif untuk mewujudkan pemerataan pendidikan di daerahnya. Namun, untuk mengatasi masalah-masalah pemerataan pendidikan tidak hanya dengan satu kebijakan saja, akan tetapi mengingat sebaran sekolah yang tidak merata, maka perlu dibuat kebijakan dengan menurunkan standar khusus untuk peserta didik dari keluarga yang kurang mampu.

\subsection{Pelaksanaan Program Indonesia Pintar dalam Mewujudkan Pemerataan Pendidikan di SDN 11 Kelampe}

Pelaksanaan Program Indonesia Pintar (PIP) di SDN

11 Kelampe dimulai pada tahun ajaran 2017/2018. SDN

11 Kelampe merupakan salah satu SDN yang status akreditasi nya Tidak Ter akreditasi. Jumlah guru di SDN 11 Kelampe adalah sebanyak 8 orang yang terdiri dari 4 guru PNS dan 4 guru honorer. Sedangkan jumlah peserta didik di SDN 11 Kelampe adalah sebanyak 36 orang, dengan rincian sebagai berikut: kelas 1 sebanyak 4 orang, kelas 2 hanya 1 orang, kelas 3 sebanyak 9 orang, kelas 4 sebanyak 8 orang, kelas 5 sebanyak 7 orang, dan kelas 6 sebanyak 7 orang. Jumlah peserta didik yang mendapatkan dana bantuan PIP pada tahun ajaran 2019/2020 pada tahap 1 sebanyak 16 orang, tahap 2 sebanyak 33 orang, serta tahap 3 sebanyak 25 orang.

Implementasi PIP di SDN 11 Kelampe sudah berjalan sesuai dengan kebijakan dan mekanisme yang ditetapkan, yaitu sosialisasi PIP kepada seluruh orang tua peserta didik, prosedur pelaksanaan PIP, tahap pengusulan penerima KIP, penetapan penerima KIP oleh Direktorat teknis, penyaluran dana oleh Bank BRI, pengambilan dana oleh orang tua peserta didik secara tunai, serta berita acara pembagian dana bantuan PIP. Kepala sekolah SDN 11 Kelampe berperan langsung sebagai penanggung jawab dalam melaksanakan PIP, dengan membentuk kepanitiaan untuk mengoordinasikan penyaluran KIP. Peserta didik yang diusulkan adalah seluruh peserta didik, karena sebagian besar keluarga peserta didik di SDN 11 Kelampe memiliki Kartu Program Keluarga Harapan (PKH)/ Kartu Perlindungan Sosial (KPS) dan Surat Keterangan Miskin (SKM). Pihak sekolah hanya mengupayakan seluruh peserta didik mendapatkan dana bantuan PIP, tetapi pada tahap penetapan peserta didik penerima KIP dan pencairan dana ditentukan dengan Surat Keputusan (SK) nama peserta didik penerima KIP yang ditetapkan oleh Kementerian Pendidikan dan Kebudayaan. Pada kenyataannya, ternyata tidak semua peserta didik yang telah diusulkan oleh pihak sekolah tercantum namanya di dalam SK yang diterbitkan. Namun, pihak sekolah tidak mudah putus asa untuk terus menerus mengusulkan nama-nama seluruh peserta didik di SDN 11 Kelampe karena mereka dirasa pantas untuk mendapatkan bantuan dana PIP.

Dengan adanya KIP diharapkan dapat menyejahterakan peserta didik agar dapat berkembang seperti halnya dalam kekurangan uang saku sehingga uang saku peserta didik dapat terpenuhi dan kekurangan pada perlengkapan sekolah juga dapat terpenuhi, serta dapat digunakan peserta didik untuk membeli peralatan sekolah termasuk biaya transportasi mereka ke sekolah sehingga pendidikan mereka menjadi layak dan juga terjamin serta tidak ada lagi peserta didik yang tidak bersekolah dengan alasan minimnya biaya pendidikan, (Prasetyono, 2018). Dana bantuan PIP melalui KIP di SDN 11 Kelampe dialokasikan untuk peserta didik yang kurang mampu untuk memenuhi kebutuhan pendukung biaya pendidikan sekolah, seperti membeli buku, alat tulis sekolah, tas, sepatu, uang saku, dll. Namun implementasinya, masih belum semua orang tua memahami dan mampu melakukannya dalam bentuk perilaku. Yang terjadi adalah sebagian dari orang tua peserta didik penerima KIP menggunakan dana bantuan untuk memenuhi kehidupan sehari-hari sehingga kebutuhan anaknya tidak terpenuhi. Perlu adanya upaya dari pihak sekolah untuk memberikan pemahaman yang mendalam kepada orang tua peserta didik tentang PIP agar tujuan PIP dapat terealisasi sebagaimana mestinya. Salah satu sebab dari masalah ini adalah karena keluarga penerima dana bantuan PIP tersebut memang berada 
dalam kondisi miskin dan serba berkekurangan, sehingga mereka lebih memilih menggunakan dana bantuan untuk kebutuhan pokok keluarganya. Meskipun demikian, adanya bantuan PIP sangat memberikan dampak yang besar bagi peserta didik yang menerima KIP di SDN 11 Kelampe. Pemanfaatan dana PIP dengan baik menjadikan peserta didik lebih antusias untuk menempuh pendidikan karena kebutuhan perlengkapan sekolah dapat terpenuhi, sehingga mereka lebih percaya diri untuk bersosialisasi dengan teman-temannya. Selain itu juga, dapat meningkatkan kemauan keluarga yang kurang mampu untuk mendaftarkan anaknya sekolah tanpa merasa khawatir dengan biaya pendidikan.

Implementasi PIP dirancang agar dapat memenuhi kebutuhan sekolah peserta didik yang berasal dari keluarga miskin, sehingga diharapkan dana PIP yang diterima oleh setiap peserta didik dapat membantu mengurangi angka putus sekolah, (Yusup, Ismanto, and Wasitohadi 2019). Besaran dana yang seharusnya diterima oleh penerima KIP di tingkat SD sebesar $450.000,00$, dana diterima langsung oleh orang tua peserta didik secara tunai melalui Bank BRI. Akan tetapi, dari hasil identifikasi ditemukan bahwa masih ada sebagian peserta didik yang menerima dana tersebut tidak secara utuh. Situasi inilah yang seharusnya tidak terjadi di lapangan. Pada dasarnya, pelaksanaan kebijakan PIP dirancang untuk memenuhi kebutuhan sekolah peserta didik yang berasal dari keluarga miskin, dengan harapan bantuan ini dapat meningkatkan partisipasi peserta didik bersekolah, juga mencegah anak putus sekolah. Untuk itu, hendaklah dibuat transparansi pelaksanaan PIP yang dilakukan melalui monitoring dan evaluasi pelaporan PIP, bahkan pengecekan hasil pelaksanaan PIP di lapangan.

Selain adanya hukum yang berlaku untuk mengatur setiap kebijakan yang ditetapkan oleh pemerintah, perlu adanya informasi yang tersedia secara bebas dan dapat diakses langsung oleh pihak sekolah maupun masyarakat yang berkepentingan, khususnya di daerah perbatasan yang tidak semua daerah dapat mengakses informasi dengan mudah karena keterbatasan infrastruktur. Transparansi tidak hanya sekadar informasi yang dapat dibaca masyarakat luas. Melainkan informasi yang dapat diakses dan mudah dipahami oleh semua kalangan adalah informasi secara terperinci yang berhubungan dengan kepentingan penerima bantuan PIP. Transparansi dianggap sangat penting dan utama oleh pihak sekolah dalam manajemen sekolah. Pemahaman akan transparansi terbatas pada pemberi dana PIP, sedangkan transparansi terhadap sekolah, peserta didik dan orang tua sebagai stakeholder masih jarang dilakukan. Inilah yang seharusnya diupayakan pihak sekolah untuk mewujudkan pemerataan pendidikan dengan memastikan terimplementasi nya transparansi dalam pengelolaan sekolah. Salah satu proses transparansi dilakukan melalui pertemuan orang tua peserta didik penerima KIP dan pihak sekolah, sehingga segala informasi dan keluhan dapat disampaikan pada saat pertemuan berlangsung.

\subsection{Permasalahan Program Indonesia Pintar dalam Mewujudkan Pemerataan Pendidikan}

Berdasarkan hasil wawancara dan hasil dokumentasi di lapangan, terdapat hal-hal penting dari penjabaran para responden mengenai permasalahan Program Indonesia Pintar dalam mewujudkan pemerataan pendidikan, sebagai berikut.

1. Respond Dinas Pendidikan dan Kebudayaan Kabupaten Bengkayang

Berdasarkan respond Kepala Bidang Pembinaan SD di Dinas Pendidikan dan Kebudayaan Kabupaten Bengkayang, Kabupaten Bengkayang memang masih tertinggal dalam bidang pendidikan, sebagaimana permasalahan mengenai PIP yang terjadi di daerah perbatasan, semakin besarnya biaya pendidikan merupakan penyebab utama dari rendahnya pemerataan pendidikan di Kabupaten Bengkayang. PIP di Kabupaten Bengkayang yang direncanakan oleh pemerintah ternyata belum dapat menjangkau semua lapisan masyarakat daerah perbatasan terutama sekolah-sekolah yang berada di pedalaman Kabupaten Bengkayang. Meskipun Data Pokok Pendidikan (Dapodik) digunakan pemerintah sebagai salah satu indikator penentuan sasaran penerima KIP, namun masih terdapat berbagai kendala terkait dengan pendistribusian yang tidak merata di daerah perbatasan. Pada sisi lain, PIP ini sudah dijalankan beberapa tahun di Kabupaten Bengkayang sehingga sudah banyak manfaatnya yang dirasakan oleh penerima KIP.

2. Respond Guru

Berdasarkan respond guru di SDN 11 Kelampe Kabupaten Bengkayang, PIP dapat menjadi salah satu solusi mengatasi persoalan minimnya biaya pendidikan dan peserta didik yang putus sekolah. Namun, kenyataannya harapan itu belum sepenuhnya terwujud. Sudah ada tumbuh rasa saling percaya antara pihak sekolah dengan peserta didik beserta orang tua terhadap penggunaan dana KIP, tetapi masih ada saja kendala dalam mempertanggungjawabkan pengelolaan dana bantuan PIP. Selain itu juga, kesadaran masyarakat akan arti pentingnya pendidikan masih sangat rendah, dikarenakan sulitnya memenuhi biaya pendidikan. Banyak para orang tua peserta didik yang lebih memilih untuk memperkerjakan anak-anak di usia sekolah guna membantu kehidupan ekonomi keluarganya daripada melanjutkan pendidikan. Tingginya angka putus sekolah dan rendahnya partisipasi pendidikan di Kabupaten Bengkayang tentu sangat membutuhkan sebuah upaya untuk mewujudkan pemerataan pendidikan.

Permasalahan lain yang terjadi adalah soal dana yang diterima oleh peserta didik hanya separuh dari jumlah yang mestinya mereka dapatkan. Belum lagi semua peserta didik yang tidak mampu sudah diusulkan oleh pihak sekolah agar bisa masuk Program Indonesia Pintar (PIP), tetapi tidak mendapatkan KIP. Dalam hal ini, belum adanya keterbukaan dari berbagai pihak, 
akibatnya masih banyak orang tua peserta didik yang kurang mampu tidak berdaya mengikuti perkembangan pendidikan serta tidak merasakan dampak positifnya dari PIP tersebut. Diharapkan PIP ini benar-benar dapat melibatkan semua peserta didik dari keluarga miskin agar masyarakat di Kabupaten Bengkayang dapat meningkatkan pemerataan pendidikan dan memperoleh pendidikan yang selayaknya.

\section{Respond Peserta didik}

Pemahaman mengenai PIP masih sangat kurang bagi peserta didik di SDN 11 Kelampe, mereka hanya mengetahui bahwa sekolah memberikan uang untuk membeli keperluan sekolah. Tidak banyak informasi yang bisa didapatkan dari peserta didik mengenai permasalahan PIP, sehingga fakta di lapangan yang diperoleh berdasarkan hasil dokumentasi yang dilakukan oleh pihak sekolah. Berdasarkan bukti berita acara, ada peserta didik yang mendapatkan dana bantuan secara tunai jumlahnya berbeda dengan teman sekelasnya, dimana peserta didik tersebut hanya menerima Rp. $75.000,00$ per semester, ada juga yang hanya menerima Rp. 225.000,00, per semester, dan Rp. 375.000,00 per semester serta ada juga yang langsung mendapatkan penuh Rp. 450.000,00. Namun, pencairan dana dilakukan bertahap, jumlah yang diterima sama besarnya, hanya saja waktu pencairan dananya yang berbeda. Meskipun demikian, hal tersebut masih menjadi pertanyaan orang tua peserta didik sehingga menimbulkan interpretasi yang salah karena mereka merasa belum ada petunjuk yang disampaikan dengan sangat jelas.

4. Respond Masyarakat

Masyarakat di Kabupaten Bengkayang mengharapkan anak-anaknya mendapatkan bantuan PIP sejak di bangku SD, bahkan kalau bisa mencapai bangku SMA hingga perguruan tinggi. Mereka mengkhawatirkan jika anaknya tidak bersekolah, akan mengalami nasib yang sama, yakni hanya menjadi seorang petani ataupun mengalami keadaan ekonomi yang tergolong miskin. Apabila dengan adanya bantuan PIP serta penyaluran dana PIP berjalan dengan lancar setiap semester, mereka bisa memperbaiki keadaan ekonominya sehingga anaknya juga tidak putus sekolah.

Masyarakat di daerah perbatasan Kabupaten Bengkayang belum secara maksimal memahami kebijakan PIP yang telah dilaksanakan. Masih banyak masyarakat yang merasa kurang dilibatkan dan kurang memahami kebijakan maupun mekanisme tentang penyaluran KIP, pemerintah terkesan bergerak sendiri tanpa melibatkan masyarakat sehingga sosialisasi yang dilakukan tidak maksimal. Keterlibatan semua pihak harus diupayakan agar program yang dijalankan dapat tercapai sesuai harapan. PIP di Kabupaten Bengkayang belum dilakukan secara berkesinambungan karena untuk memenuhi pemerataan pendidikan di daerah perbatasan menuntut pendanaan yang cukup besar, tidak hanya berkaitan dengan sarana dan prasarana saja, tetapi juga hal yang terpenting adalah memelihara peserta didik agar dapat memperoleh Pendidikan.

\subsection{Solusi dan Harapan}

Dalam menjalankan tugasnya pihak sekolah belum banyak memberikan masukan yang nyata menyangkut implementasi PIP, karena evaluasi pelaksanaan PIP ditangani oleh pemerintah pusat. Pemerintah harus tanggap dengan masalah-masalah mendasar di masyarakat serta harus mau bekerja sama dengan pemerintah daerah mencari solusi yang tepat untuk mengatasi permasalahan PIP khususnya di daerah perbatasan. Permasalahan di daerah perbatasan Kabupaten Bengkayang sangat kompleks, sehingga memerlukan metode pemerataan pendidikan yang lebih terarah, oleh sebab itu perlu adanya keterlibatan seluruh pemangku kepentingan. Diharapkan pada periode selanjutnya semua pemangku kepentingan harus terlibat dan saling mendukung agar penyaluran bantuan PIP mampu mewujudkan pemerataan pendidikan secara berkelanjutan.

Berdasarkan kondisi masyarakat di Kabupaten Bengkayang bahwa kendala yang lazim dikeluhkan adalah mengenai biaya sekolah yang tidak dapat terpenuhi karena masalah ekonomi. Adapun bantuan PIP yang diberikan belum tentu dapat menutupi kekurangan ekonomi mereka. Oleh karena itu, solusi yang dapat ditawarkan untuk mengatasi kendala tersebut adalah pengawasan yang menyeluruh terhadap implementasi PIP melalui pendistribusian KIP di semua sekolah dari berbagai jenjang di Kabupaten Bengkayang. Pemerintah daerah maupun pihak sekolah harus terus menerus turut andil mengevaluasi pelaksanaan PIP, serta masyarakat juga harus terlibat aktif dalam meningkatkan angka partisipasi pendidikan yang menghasilkan terwujudnya pemerataan pendidikan di Kabupaten Bengkayang.

Pemerataan pendidikan di Kabupaten Bengkayang harus dapat memenuhi aspek penting yaitu Equality dan Equity. Equality berarti masyarakat Kabupaten Bengkayang mendapatkan kesempatan untuk memperoleh pendidikan, sedangkan equity bermakna masyarakat Kabupaten Bengkayang mendapatkan keadilan dalam memperoleh kesempatan pendidikan yang sama diantara berbagai kelompok dalam masyarakat. Akses terhadap pendidikan yang merata berarti semua penduduk usia sekolah mulai di bangku SD hingga bangku SMA telah memperoleh kesempatan pendidikan, sementara itu akses terhadap pendidikan telah adil jika antar kelompok bisa menikmati pendidikan secara sama terutama masyarakat kelas bawah. Coleman dalam bukunya Equality of educational opportunity mengemukakan secara konvensional konsep pemerataan yakni: pemerataan aktif dan pemerataan pasif. Pemerataan pasif adalah pemerataan yang lebih menekankan pada kesamaan memperoleh kesempatan untuk mendaftar di sekolah, sedangkan pemerataan aktif bermakna kesamaan dalam memberi kesempatan kepada peserta didik yang terdaftar agar memperoleh hasil belajar setinggi-tingginya. Dalam pemahaman seperti ini pemerataan pendidikan mempunyai makna yang luas tidak hanya persamaan dalam memperoleh kesempatan 
pendidikan, tetapi juga setelah menjadi peserta didik harus dapat memenuhi kebutuhan sekolah guna memperoleh pendidikan sehingga merasa percaya diri untuk mengembangkan potensi yang dimilikinya secara optimal.

\section{KESIMPULAN}

Permasalahan PIP di Kabupaten Bengkayang adalah pendistribusian KIP yang tidak merata, pencairan dana PIP tidak secara utuh, peserta didik penerima KIP tidak tepat sasaran, masih ada orang tua penerima KIP yang tidak mengelola dana bantuan PIP dengan baik, masyarakat kurang dilibatkan dalam pelaksanaan PIP, serta sebagian besar masyarakat kurang memahami kebijakan maupun mekanisme penyaluran dana bantuan PIP. Solusi yang dikemukakan oleh masyarakat untuk mewujudkan pemerataan pendidikan adalah dengan terus menerus mendorong adanya keterlibatan semua pihak untuk bekerja sama saling memantau dan mengevaluasi pelaksanaan PIP di daerahnya secara menyeluruh dan seimbang. Apabila ada kendala dalam implementasinya harus segera ditindaklanjuti oleh pihak terkait, sehingga dalam jangka panjang keberhasilan PIP selalu tercapai dan dapat menyelesaikan persoalan pendidikan di Kabupaten Bengkayang, khususnya masalah peserta didik yang tidak dapat bersekolah serta putus sekolah karena tidak memiliki biaya.

\section{SARAN}

Keberhasilan PIP memerlukan keterlibatan banyak pihak, pemerintah daerah hendaknya dapat menjamin bahwa dengan adanya PIP dapat membantu peserta didik bebas dari segala bentuk biaya keperluan sekolah serta dapat menarik peserta didik yang putus sekolah untuk bersekolah kembali. Di sisi lain dibutuhkan konsistensi dari pihak sekolah dan komitmen dalam mengupayakan peserta didik yang kurang mampu untuk diusulkan mendapatkan bantuan PIP dan mendorong seluruh peserta didik untuk mengembangkan hasil belajarnya. Koordinasi pihak sekolah dengan pemerintah daerah juga dibutuhkan. Hal ini dapat diwujudkan dalam kegiatan sosialisasi kepada peserta didik maupun orang tua peserta didik agar lebih paham mengenai kebijakan PIP, sehingga peserta didik yang menerima KIP dapat memanfaatkan dan mengelola dana PIP dengan sebaikbaiknya sesuai keperluan sekolah.

\section{DAFTAR PUSTAKA}

Aristo, T. J. V. 2019. Analisis Permasalahan Pemerataan Pendidikan di Kabupaten Sintang. Jurnal Akuntabilitas Manajemen Pendidikan, 7(1), 25-34.

Astuti, R. S. 2017. "Implementasi Kebijakan Kartu Indonesia Pintar Dalam Upaya Pemerataan Pendidikan Tahun Ajaran 2015 / 2016 Di Smp N 1 Semin.” Jurnal Kebijakan Publik Edisi 2, 21-27. http://eprints.uny.ac.id/id/eprint/47597.

Badan Pusat Statistik Kabupaten Bengkayang. 2020.
Kabupaten Bengkayang dalam Angka 2020. https://bengkayangkab.bps.go.id/publication/downl oad.html (diakses tanggal 21 Agustus 2020)

Mujahidun, M. 2016. Pemerataan Pendidikan Anak Bangsa: Pendidikan Gratis Versus Kapitalisme Pendidikan. Jurnal Tarbiyatuna, 7(1), 38-52.

Mukhtar, 2013, Metode Penelitian Deskriftif Kualitatif. Jakarta: GP Press Group.

Prasetyono, D. W. 2018. Implementasi Program Kartu Indonesia Pintar (KIP) Di SMA Negeri 2 Dumoga. MAP (Jurnal Manajemen dan Administrasi Publik), 1(01), 15-30.

Purnasari, P. D., \& Sadewo, Y. D. 2019. Pendidikan Ketahanan Sosial dan Ekonomi dalam Meningkatkan Karakter Nasionalisme dan Wawasan Bela Negara. Seminar Nasional dan Call For Paper Bela Negara (pp. 64-70). Bogor: Universitas Pertahanan.

Rohaeni, N. E., \& Saryono, O. 2018. Implementasi Kebijakan Program Indonesia Pintar (PIP) Melalui Kartu Indonesia Pintar (KIP) dalam Upaya Pemerataan Pendidikan. Journal of Education Management and Administration Review, 2(1), 193204.

Septiandika, V. 2017. Evaluasi Implementasi Penyaluran Program Indonesia Pintar (PIP) Bagi Siswa Kurang Mampu (Studi pada SDN Jrebeng Wetan Tahun 2016). Pedagogy, 4(1), 52-56.

Sugiyono, 2010, Metode Penelitian Kuantitatif Kualitatif dan $R \& D$. Bandung: Alfabet

Yusup, W. B., Ismanto, B., \& Wasitohadi, W. (2019). Evaluasi Program Indonesia Pintar dalam Peningkatan Akses Pendidikan di Sekolah Menengah Pertama. Kelola: Jurnal Manajemen Pendidikan, 6(1), 44-53. 